\title{
무선센서네트워크에서QOS지원을위한다중계층MAC프로토콜
}

\author{
김 성 철*, 박 현 주**
}

\section{A QoS Aware multi-layer MAC(QAML-MAC) Protocol for Wireless Sensor Networks}

\author{
Seong-Cheol Kim*, Hyun-Joo Park **
}

\section{요 약}

본 논문에서는 무선센서 네트워크에서 전송될 데이터의 $\mathrm{QOS}$ 를 인지하여 이를 지원하는 다중 계층 $\mathrm{QAML}-$ $\mathrm{MAC}(\mathrm{Q} 0 \mathrm{~S}$ Aware Multi-layer MAC) 프로토콜을 제안한다. 제안된 프로토콜은 노드들의 에너지를 효율적으로 사용함 으로 전체 네트워크의 수명을 늘이는 방법 중의 하나인 sleep-awake 구조를 기반으로 한다. 이를 위하여 노드에 입력되 는 데이터를 전송 응급성에 따라 우선순위 클래스로 나누어 저장한다. 또한 cross-layer 개념을 도입하여 동일한 목적지 로 향하는 데이터를 재정돈한다. 제안된 MAC 프로토콜은 기존 관련 프로토콜의 문제점인 지연(delay)을 줄이는 동시에 실시간의 멀티미디어 트래픽 혹은 미리 정해진 필드 모니터링과 같은 응용에서 임계값을 초과하는 데이터와 같은 우선순위 가 높은 데이터를 빠르게 전송함으로써 전송에 응급한 데이터를 먼저 전송할 수 있는 장점을 가진다. 뿐 만 아니라 각 노드 에서 전송할 우선순위 데이터가 존재하지 않을 경우 idle listen에 있어서 다중의 계층을 사용함으로 데이터전송에서의 충 돌을 줄임으로 노드에서 소모하는 에너지를 줄이며, 결국 전체 네트워크 수명을 늘일 수 있는 장점을 가진다.

- 키워드 : 무선센서네트워크, 서비스의 질, 다중접근제어

\section{Abstract}

In this paper, we propose an QoS aware multi-layer MAC(QAML-MAC) protocol in a wireless sensor networks. Since the proposed protocol is based on the sleep-awake architecture, which save node's energy to prolong the entire network lifetime. For this purpose the QAML-MAC first classifies incoming data according to their transmission urgency and then saves them. The protocol also adapts the cross-layer concept to re-arrange the order of transmission with the same destination. So the delay can be decreased, which can not be obtained with the previous related protocols. And high priority data such as real-time multimedia or critical value in the field monitoring applications can be transmitted quickly, Furthermore the proposed protocol has advantage of decreasing transmitted data collisions using multiple layers of idle listening when there is no high-priority data. So energy consumptions of sensor nodes can be saved and the network lifetime can be prolonged.

- Keyword : Wireless Sensor Networks, Quality of Service, MAC

- 제1저자 : 김성철 교신저자 : 김성철

- 투고일 : 2010-10-26, 심사일 : 2010-11-23, 게재확정일 : 2011-01-03

* 상명대학교 컴퓨터과학부(Div. of Computer Science, Sangmyung Univisity)

** 상명대학교 컴퓨터과학과 박사과정(Div. of Computer Science, Sangmyung Univisity)

※ 본 연구는 2010년도 상명대학교 교내연구비 지원을 이루어졌음 


\section{I. 서 론}

무선 센서 네트워크(Wireless Sensor Networks)는 환 경 모니터링, 빌딩 관리, 물체 추적, 군사용 등 다양한 분야에 많이 적용되어지고 있는 실정이다. 이러한 응용분야에서 $\mathrm{WSNs}$ 의 중요한 역할로는 목적지(target) 영역에 대한 모니 터링과 각 센서 노드로부터 수집된 데이터를 전달하는 것이 다. 일반적으로 WSNs는 스스로 다중 홉 무선 네트워크를 구 성하고 있는 많은 수의 센서노드들로 구성된다. 각 센서 노드 들은 낮은 전력 신호를 사용하여 서로 통신한다. 그러나 다른 무선 네트워크와는 달리 배터리에 의해 동작되는 무선센서 네 트워크의 전체 네트워크 수명 연장을 위하여 각 센서 노드들 의 효율적인 에너지 사용이 필요하다. 센서 노드들의 idle listening은 에너지 낭비하는 요소 중의 하나이다. 따라서 idle listening을 줄임으로써 에너지 소모를 막으려는 여러 가지 연구 결과들이 제안되었다[1][2]. 그 중에서 가능하면 센서 노드로 하여금 주기적으로 자신의 라디오(radio)를 끄 고 수면(sleep) 상태로 머물게 함으로써 에너지를 절약하려 는 방법이 좋은 방법으로 인식되어 이에 대한 많은 연구가 진 행되었다. 이들 연구 결과들의 대부분은 가능한 한 listen 구 간을 늘이고 수면 구간을 늘임으로써 에너지를 절약하는 효과 를 얻을 수 있으나, 전송되어지는 데이터의 지연을 크게 하는 문제점을 가진다.

에너지 효율적인 사용과 전체 네트워크 수명의 연장 이외 에도 $\mathrm{WSNS}$ 에서 다루어져야 할 문제는 서비스의질(QOS: Quality of service)의 지원이다. 특히 물체추적(object tracking)혹은 데이터 수집(data gathering)과 같이 실시 간 데이터들은 효율적인 에너지 사용과 더불어 $\mathrm{QOS}$ 지원을 필요로 한다[6][7][8]. 그러나 $\mathrm{WSNS}$ 에서 실시간 혹은 신뢰 성 있는 전송을 요구하는 서비스들에 대하여 차별화된 지원을 하기 위해서는 자체 특성으로 인하여 여러 가지 해결해야 할 문제들을 가진다. 즉, 무선 채널이 비신뢰적이며 예측불가능 하다는 것, 무선 매체가 여러 사용자에 의해 공유됨으로 인하 여 충돌이 발생할 수 있다는 것, 노드들이 제한된 에너지만을 가지고 재충전하기 어렵다는 것, 마지막으로 네트워크 토폴로 지가 자주 변한다는 것들이다. 이로 인하여 IEEE 802.11과 같은 기존 무선 네트워크에서 제안되었던 $\mathrm{QOS}$ 지원 프로토콜 이 그대로 $\mathrm{WSNs}$ 에 적용할 수 없다.

$\mathrm{WSNS}$ 에서 QOS 지원 문제와 에너지의 효율적인 사용은 일반적으로 분리된 문제로 취급되었다. 그러나 본 논문에서는 에너지의 효율적인 사용으로 전체 네트워크 수명을 늘이면서
각 데이터의 전송 응급성에 따른 $\mathrm{QOS}$ 우선순위를 정하여 차 별화된 전송을 할 수 있으며, 멀티미디어 트래픽과 같이 실시 간 전송이 요구되는 데이터들이 가지는 버스티(bursty)한 트 래픽의 전송을 빠르게 하기 위하여 전송되는 데이터 패킷을 재정돈하여 전송하는 cross-layer 방식을 결합한 통합 $\mathrm{MAC}$ 프로토콜을 제안한다. 제안된 프로토콜은 실시간 트래픽과 비 실시간 트래픽이 존재하는 응용 혹은 환경 모니터링 응용에서 임계값을 넘는 경우 경보가 필요한 응용 등에 유용하게 사용 될 수 있다. 이를 위해 제안된 프로토콜에서는 전송 응급성에 따라 결정된 우선순위에 해당하는 독립의 큐에 저장되며, 저 장 시에 동일한 목적지로 향하는 데이터를 재정돈하여 함께 전송함으로써 우선순위의 데이터를 빠르게 전송할 수 있는 장 점을 가진다.

본 논문의 구성은 다음과 같다. 2절에서는 WSNs에서 $\mathrm{QOS}$ 지원에 대한 관련 연구에 대해 알아보고, 본 논문에서 제안한 $\mathrm{QAML}-\mathrm{MAC}$ 에 대한 설명이 3절에서 이루어진다. 또한 4절에서는 $\mathrm{QAML}-\mathrm{MAC}$ 과 기존의 관련 프로토콜과의 성능 비교가 이루어지며, 마지막으로 결론이 5절에서 이루어 진다.

\section{II. 기존 연구}

제한된 에너지의 공급 및 다양한 목적을 가지는 $\mathrm{WSNs}$ 에 서 지연, 패킷 손실, 대역폭 등 $\mathrm{QOS}$ 를 지원하기 위해서 기존 의 다른 네트워크에서 제안된 프로토콜을 그대로 적용할 수 없 다. 따라서 일반적으로 네트워크에서 요구하는 $\mathrm{QoS}$ 를 지원하 기 위해서는 특정 계층에만 의존하지 않고 여러 계층에서의 협 업을 통한, 즉 cross-layer 설계에 의존하는 경우가 많다[3]. 본 논문에서도 $\mathrm{MAC}$ 계층 및 네트워크 계층의 일부 기능을 통 해 $\mathrm{QOS}$ 를 지원하는 프로토콜에 초점을 맞추기로 한다.

$\mathrm{MAC}$ 프로토콜의 기본 역할은 이웃 노드들끼리 서로 통신 하기 위하여 공유 라디오 채널에 어떻게 노드들이 접근하는가 를 제어하는 일이다. WSNs에서의 MAC의 역할은 이 외에도 각 노드에서의 에너지 효율적인 사용이라는 중요한 기능도 담 당해야 한다. $\mathrm{WSNS}$ 에서 $\mathrm{QOS}$ 지원에 대한 연구가 그 동안 많이 이루어졌다[6][7][8][9][10]. WSNs에서의 MAC 프 로토콜이 일반적으로 스케줄기반(scheduled based) 프로토 콜과 경쟁기반(contention-based) 프로토콜로 나누어진 것 처럼, $\mathrm{QOS}$ 지원에 대한 프로토콜도 이 두 프로토콜의 기반으 로 연고되어져 왔다. 그 중 [6]에서 제안된 프로토콜은 $\mathrm{SMAC}$ 과 같이 경쟁기반 $\mathrm{MAC}$ 프로토콜로써 실시간 전송이 요구되는 멀티미디어 트래픽을 전송함에 있어서 듀티 사이클 
(duty cycle) 및 충돌 윈도우(contention window)를 능동 적으로(dynamically) 조절한다. 이를 위하여 일정 구간 동 안 전송된 트래픽 중 지배적인(dominant) 트래픽에 따라 활 성화 시간(active time: TA)을 설정하여 듀티 사이클을 조 절함으로 $\mathrm{QOS}$ 를 지원한다. 그러나 [6]에서 제안된 알고리즘 에서는 동일한 지배적인 트래픽일지라도 구성되는 다른 특성 의 트래픽을 고려하지 않을 뿐 만 아니라, 측정하는 구간 등 의 여러 요소에 의해 제한받는 문제점을 가진다.

또한 [10]에서 제안된 $\mathrm{EQ}-\mathrm{MAC}$ 에서는 우선순위에 따라 트래픽을 구분해 주는 분류기(Classifier) MAC과 채널 액세 스 $\mathrm{MAC}$ 을 통하여 $\mathrm{QoS}$ 를 지원해준다. 제안된 $\mathrm{EQ}-\mathrm{MAC}$ 은 클러스터 기반의 $\mathrm{MAC}$ 프로토콜로써 전송하는 노드의 결정 은 경쟁기반이지만, 데이터 전송에 있어서는 클러스터 헤드가 슬롯을 할당하는 TDMA 방식을 사용함으로써 하이브리드 (Hybrid) 구조를 가진다. 그러나 $\mathrm{EQ}-\mathrm{MAC}$ 은 기본적으로 센서 노드들과 헤드 노드 사이의 원 홉(hop) 구조에만 적용 가능하므로 여러 홉으로 구성되는 실재의 WSNs에는 정확히 적용하기 어려운 문제점을 가진다. WSNs에서의 문제점인 에 너지 효율적인 사용과 $\mathrm{QOS}$ 지원을 통합한 프로토콜이 [7]에 서 제안되었다.

[7]에서 제안된 시스템은 응용계층으로부터의 QOS 요구 사항과 데이터링크와 물리 계층에서의 변조 및 전송 방식 등 이 합해진 통합 무선 전송 시스템이다. 뿐 만 아니라 여기서 제안된 프로토콜은 클러스터 기반으로 인터 클러스터 (intra-cluster)와 인트라 클러스터(inter-cluster)로 구분 되어진다. 따라서 클러스터헤드는 다중 홉 백본을 형성한다. 그러나 사용되어지는 파라미터들의 값에 따라 성능에 많은 영 향을 미치는 문제점을 가진다. 이 외에도 [11]에서 제안된 Q-MAC 구조에서는 우선순위에 기반으로 네트워크 서비스를 차별화함으로써 $\mathrm{QoS}$ 를 지원한다. 여기에서 말하는 우선순위 레벨의 차이는 서로 다른 센서노드들로부터 측정되어진 데이 터의 응급성을 반영하여 결정된다. 이를 위하여 내부 노드간 (intra-node) 스케줄링 스케줄링과 외부 노드간 (inter-node) 스케줄링을 사용한다. 본 논문에서의 우선순위 버퍼의 사용은 바로 이 $\mathrm{Q}-\mathrm{MAC}$ 의 인트라 노드 스케줄링의 방식을 따른다. 본 논문에서 제안된 $\mathrm{QAML}-\mathrm{MAC}$ 은 $\mathrm{Q}-\mathrm{MAC}$ 과 패킷의 응급성에 따라 전송우선 순위를 달리하는 면에서는 동일하나, 전송된 패킷의 목적지에 따르는 전송 순 서의 변경과 전송되는 패킷에 따른 각 노드에서의 전송 스케 줄을 달리함으로 에너지 효율 및 지연을 줄일 수 있는 장점을 가진다.

\section{QAML-MAC}

본 논문에서 제안된 $\mathrm{QAML}-\mathrm{MAC}$ 은 경쟁기반의 프로토콜 이며 다음의 두 요소로 이루어진다. 첫 번째는 데이터의 우선 순위 클래스를 구분하여 각각 클래스의 버퍼에 저장하는 것이 다. 이 때 cross-layer 개념을 사용하여 동일한 목적지로 향 하는 데이터를 인접하게 배치한다, 두 번째는 각 센서 노드들 로 하여금 listen 구간에서의 에너지 소비를 줄이기 위하여 listen 구간을 나누어 오버래핑이 되지 않도록 계층화하여 할 당하는 것이다. 이는 [5]에서 제안한 $\mathrm{ML}-\mathrm{MAC}$ 에 기반을 두 는데, $\mathrm{ML}-\mathrm{MAC}$ 에서는 각 노드들이 매우 짧은 idle listening 시간을 가짐으로 다른 노드들과 통신하는데 필요한 에너지를 줄이며, 동시에 충돌을 줄일 수 있다.

$\mathrm{QAML}-\mathrm{MAC}$ 은 다음과 같이 동작한다. 먼저 각 센서 노 드들은 전송 받은 데이터를 클래스로 구분하여 각각의 버퍼에 저장한다. 아래의 그림1은 이웃 노드로부터 전송 받은 데이터 를 각 우선순위에 따라 별도의 버퍼에 저장하는 메커니즘을 보여주고 있다. 그림 1 에서 볼 수 있듯이 이웃 노드로부터 받 은 패킷은 패킷의 응급성에 따라 패킷 분류기에서 우선순위 버퍼와 우선순위가 낮은 버퍼로 저장되어 순서에 따라 다음 노드로 전달되어 진다.

데이터의 클래스를 구분하기 위하여 각 센서 노드들은 자 신이 측정한 값 혹은 이웃 노드로부터 받은 데이터의 전송 긴 급성(transmission urgency)[3]에 따라 우선순위를 부여 한다. 전송 긴급성 $\mu$ 는 응용계층의 중요성에 따른 패킷 긴급 성 $\left(C_{c}\right)$, 재전송 비용을 나타내는 전송 홉(transmission hops) $\left(H_{c}\right)$, 잔여 에너지(residual energy) $\left(E_{c}\right)$, 그리고 큐의 비례 적인 부하(queue's proportional load)에 영향을 받는데 그 관 계식은 다음과 같다.

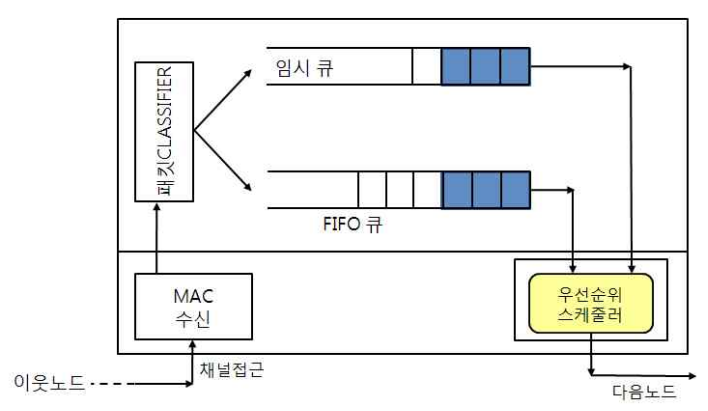

그림 1. 수신된 데이터의 우선순위에 따르는 버퍼할당 Fig. 1 Buffer Allocation of received Data according to the Priority 
$\mu=\frac{1}{4} \times\left(\frac{E_{c}}{E_{\max }}+\lambda+\frac{C_{c}}{C_{\max }}+\frac{H_{c}}{H_{\max }}\right)$.

이다. 여기서 큐의 비례적인 부하는 다음과 같다.

$\lambda=\frac{1}{2} \times\left(\frac{\sum_{i=1}^{n} w_{i} Q_{c}(i)}{\sum_{i=1}^{n} w_{i} Q(i)}+\max _{k=1 \ldots n}\left(\frac{Q_{c}(k)}{Q(k)}\right)\right) \ldots \ldots \ldots \ldots \ldots$ (2)

위의 식에서 $E_{\mathrm{max}}$ 는 초기 에너지, $H_{\mathrm{max}}$ 는 허용된 최 대 홉 수, $C_{\mathrm{max}}$ 는 패킷의 긴급성 레벨을 나타낸다. 또한 $n$ 은 큐의 수, $w_{i}$ 는 $i$ 번째 큐의 서비스 가중치, $Q_{i}$ 와 $Q_{c}(i)$ 는 부하의 최대치와 순간치를 나타낸다. 위의 식 (1)에서 볼 수 있듯이 전송 긴급성 $\mu$ 는 에너지, 큐의 부하, 패킷의 긴급성, 그리고 홉의 수에 영향을 받는다. 따라서 응용 및 환경에 따라 위의 각 항목에 가중치를 다르게 사용함으로 패킷의 전송에 정확도를 높일 수 있을 것이다. 위의 식을 통해 얻은 값으로 센서 노드의 우선순위 값 $\mathrm{\rho}$ 와 충돌 시간 $t_{C T}$ 은 다음의 식 (3)과 (4)로 주어진다. 이들 식에서 $\mu$ 값은 위의 식 (1)에서 얻 어진 값이고, $N$ 은 우선순위 레벨 값, 그리고 $C W$ 는 충돌윈 도우의 크기를 나타낸다.

$$
\begin{aligned}
& \rho=\max (\lfloor(1-\mu) \times N\rfloor, N-1) \cdots \cdots \cdots \cdots \cdots \cdots(3) \\
& t_{C T}=\rho \times C W+\operatorname{rand}(C W) \cdots \cdots \cdots \cdots \cdots \cdots \cdots \cdots \cdots \cdots \cdots \cdots \cdots(4)
\end{aligned}
$$

여기서 본 논문에서는 편이를 위해 우선순위가 높은 데이터 와 낮은 데이터 두 종류로 구분하였으나 이는 적용되는 응용에 따라 여러 레벨로 확대되어 질 수 있다. 높은 우선순위의 데이 터의 예로써 멀티미디어 응용 관련 데이터 혹은 미리 정해진 임계값보다 높은 비정상적인 측정값을 들 수 있다. 일반적으로 우선순위가 높은 데이터는 지연에 민감한(delay sensitive) 데이터이다. 각 노드에서는 자신이 측정한 데이터 혹은 전달받 은 데이터에 대해 앞의 식 (3)에 의해 결정된 우선순위에 따라 해당 FIFO 큐에 넣는다. 이때 우선순위에 따라 각각 독립된 $\mathrm{FIFO}$ 큐에 들어온 데이터는 각각 목적지가 다를 수 있다. $\mathrm{FIFO}$ 큐의 특성 상 먼저 들어 온 데이터는 먼저 서비스를 받 는다. 따라서 FIFO 큐에 들어 있는 데이터의 목적지가 다른 데이터가 섞여서 전송되어질 때에 많은 노드들이 데이터 전송
에 참여하게 된다. 아래의 그림 2는 sleep-awake 구조를 가 지며 에너지를 절약하는 대표적인 SMAC[1] 프로토콜에서의 데이터 전송방식을 보여 준다.

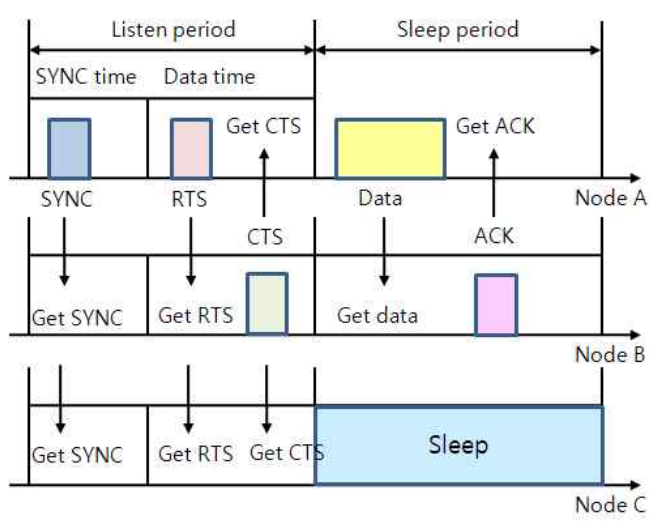

그림 2 SMAC에서의 데이터 전송 과정

Fig. 2 Data Transmission Process in SMAC

그림 2의 예에서 노드 $\mathrm{A}$ 가 보낼 데이터를 가지고 있을 때 이웃인 노드 $\mathrm{B}$ 와 노드 $\mathrm{C}$ 에게 $\mathrm{SYNC}$ 패킷을 전송하고 수신자 인 노드 B에게 RTS(Request-To-Send) 패킷을 보낸다. RTS 패킷을 받은 노드 B는 이에 대한 응답으로 CTS를 보낸 후 수면 구간에서 데이터를 전송 받는다. 그러나 노드 $\mathrm{C}$ 는 수 면 구간 동안 수면을 지속하게 된다. 즉, 데이터 전송에 참여하 지 않는 노드들은 수면 모드에 머물기 때문에 idle listening 에서 발생하는 에너지 소모를 막을 수 있다.

그러나 SMAC에서는 위와 같은 메커니즘을 사용하여 에너 지를 절약하지만 고정된 listen 및 수면 구간으로 인하여 데이 터가 없을 경우에도 고정된 listen 구간을 가지므로 에너지를 더 소비하게 된다. 이처럼 listen 구간에 데이터 전송이 없을 경우 바로 수면 모드로 가게 함으로 에너지를 절약할 수 있는 $\mathrm{TMAC}[2]$ 이 제안되었다. 그러나 SMAC이나 TMAC 모두 에너지를 효율적으로 사용하는 장점을 가지는 대신에 패킷 전 송에서의 지연이 증가한다는 문제점을 가진다. 뿐 만 아니라 송신자와 수신자가 서로 다른 스케줄을 가질 수 있고, 또한 $\mathrm{FIFO}$ 스케줄링을 따르기 때문에 추가적인 지연이 발생할 수 있다[3]. 따라서 본 논문에서는 데이터의 전송되어지는 목적 지에 따라 데이터의 전송순서를 바꾸어 전체 네트워크의 전송 에너지를 줄이는 방법을 사용한다. 즉, 하나의 노드에서 전송 하는 데이터의 목적지에 따라 전송 순서를 바꾸어줌으로써 $\mathrm{FIFO}$ 스케줄링으로 인하여 발생하는 지연문제를 해결한다. 이를 위하여 각 노드는 임시 버퍼(temporary buffer)를 생성 하여 목적지에 따르는 데이터의 순서를 바꾸어 동일한 목적지 
로 향하는 패킷을 우선적으로 전송하게 된다. 이 기능은 $\mathrm{MAC}$ 계층에서 이루어질 수 없기 때문에 본 논문에서 제안된 프로토 콜은 cross-layer 구조를 가진다. 요약하면 다음과 같다.

- 데이터의 우선순위에 따라 위의 식 (3)에 얻은 값에 따라 서로 다른 버퍼에 넣는다.

- 버퍼에 있는 데이터 중 동일한 목적지를 가지는 데이터 를 모아 순서를 재 정돈한다.

하나의 노드에는 우선순위에 따라 여러 개의 버퍼를 가지 게 된다. 우선순위가 높은 버퍼에 들어 있는 데이터 전송이 완료된 이후에 우선순위가 낮은 버퍼에 있는 데이터들이 전송 되어진다. 그러나 본 논문에서는 우선순위를 가지는 데이터와 그렇지 않은 데이터를 가지는 경우만을 고려하기로 한다.

두 번째 요소는 에너지 효율적인 이용을 위한 listen 구간 을 오버래핑이 되지 않는 다중의 구간에 소속하는 것이다[5]. [5]에서 제안된 $\mathrm{ML}-\mathrm{MAC}$ 은 기존의 listen-sleep 구조를 가 지는 에너지 효율적인 $\mathrm{MAC}$ 프로토콜이다. SMAC이나 $\mathrm{TMAC}$ 에서는 모든 노드들이 동일한 listen 구간과 수면 구 간을 가진다. 따라서 위에서 언급한대로 긴 idle listening에 따르는 에너지를 소모한다. 그러나 $\mathrm{ML}-\mathrm{MAC}$ 에서는 그림 3 에서와 같이 각 노드들로 하여금 중첩되지 않는 짧은 listen 구간을 가지게 함으로써 idle listening 구간에서 소모하는 에너지를 절약하게 된다. 각 계층의 수는 $\mathrm{WSNs}$ 에서 지원되 는 클래스의 수와 같게 할 수 있다.

본 논문에서 제안된 $\mathrm{QAML}-\mathrm{MAC}$ 의 $\mathrm{QoS}$ 지원은 이 아이 디어를 사용하여 다음과 같은 순서에 의해 이루어진다.

- 각 센서 노드들은 각자 오버래핑 되지 않은 listen 구 간을 가지는 스케줄과 $\mathrm{SMAC}$ 혹은 $\mathrm{TMAC}$ 과 같이 모 든 노드들이 공통으로 가지는 스케줄을 모두 가진다.

- 각 노드에서 우선순위가 높은 버퍼의 데이터를 전송할 경우

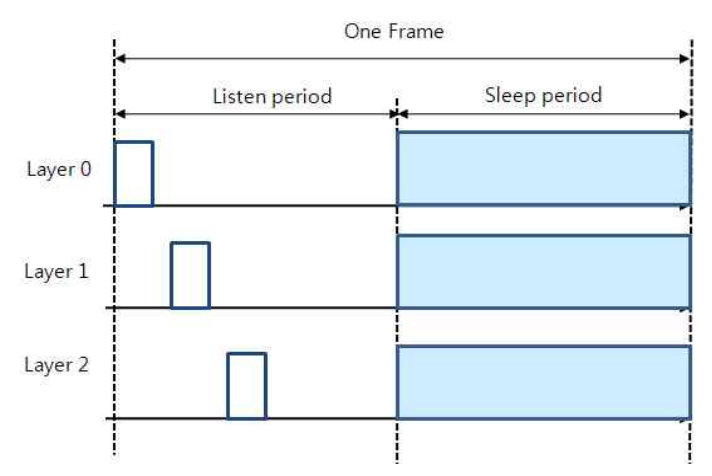

그림 3. listen 구간의 계층화로 인한 에너지 절약 Fig 3. Energy saving with layered listen period sync 구간에서 모든 노드들이 가지는 공통 스케줄을 전송한 다. 이 스케줄을 가지는 모든 노드들은 이 스케줄에 동기화한 다. 따라서 모든 노드들은 TMAC과 같이 동작한다. 다만 이 경우에 각 버퍼에서는 동일 목적지로 향하는 데이터를 재정돈 하여 저장한 후에 전송한다.

- 각 노드에서 우선순위가 낮은 데이터를 전송할 경우 에는 기존에 자신이 속한 다중의 listen 계층에서 가 지는 스케줄을 따른다.

\section{IV. 성능비교}

본 장에서는 본 논문에서 제안한 $\mathrm{QAML}-\mathrm{MAC}$ 과 기존의 $\mathrm{MAC}$ 과의 성능을 비교한다. 기존의 $\mathrm{MAC}$ 과의 차이는 기본적 으로 동일한 listen-sleep 구조를 가지므로 지연의 비교에서는 주로 패킷 전송의 스케줄링 부분이다. 그러나 $\mathrm{QAML}-\mathrm{MAC}$ 은 데이터의 전송 응급성에 따르는 $\mathrm{QOS}$ 의 지원은 물론 적은 listen 구간의 사용 및 충돌 확률을 줄임으로써 각 노드에서의 에너지 소모를 줄여 전체 네트워크의 수명을 연장할 수 있다.

본 논문의 성능 분석을 위하여 대략 $100 \mathrm{~m} \mathrm{X} 100 \mathrm{~m}$ 공간 에 100 개의 센서 노드가 있다고 가정한다. 아래의 그림에서 얻은 값들은 100 개의 센서노드들을 10 번 임의로 분포를 변 경하여 얻어진 평균값을 취한다. 표 1 은 본 논문에서 사용한 파라미터들의 값을 보여준다. 또한 아래의 성능 비교를 위하 여 각 노드들은 전송하는 전체 데이터 중 $30 \%$ 가 우선순위 트 래픽 즉, 멀티미디어와 같은 실시간 트래픽 혹은 초기에 설정 된 임계값을 초과하는 비정상(abnormal) 데이터를 가진다고 가정하였다. 즉, 성능 비교를 위한 시뮬레이션에서는 우선순 위가 높은 트래픽과 낮은 트래픽 두 개의 계층(layer)만 존재 한다고 가정하였다. 뿐 만 아니라 우선순위 데이터를 가지는 노드들은 우선순위 버퍼에 저장되어 있는 데이터를 먼저 전송 한 이 후에 다른 데이터를 전송한다고 가정하였다.

표 1. 시스템 환경

Table 1. System Environments

\begin{tabular}{|c|c|c|}
\hline 파라미터 & 값 & 설명 \\
\hline Duty Cycle & 10 & \\
\hline Data_CW & 63 & 최대윈도우크기 \\
\hline Short_CW & 31 & 최대윈도우크기 \\
\hline$P_{t}$ & 0.2818 & 전송전력소모(W) \\
\hline$P_{r}$ & 0.3682 & 수신전력소모(W) \\
\hline$P_{\text {idle }}$ & 0.3442 & idle전력소모 \\
\hline$P_{\text {sleep }}$ & 0.00005 & sleep전력소모 \\
\hline$P_{\text {init }}$ & 1000 & 초기에너지(J) \\
\hline
\end{tabular}


아래의 그림 4는 본 논문에서 제안된 QAML-MAC의 기 존 $\mathrm{MAC}$ 과의 지연에 대한 비교이다. 그림 4 에서 보여 주는 바와 같이 본 논문에서 제안된 $\mathrm{QAML}-\mathrm{MAC}$ 은 우선순위를 가지는 데이터에 대하여 평균지연이 낮음을 볼 수 있다. $\mathrm{SMAC}$ 은 기본적으로 우선순위를 지원하지 않기에 전송된 전 체 데이터의 평균 지연을 나타낸다. 또한 평균 inter-arrival 시간이 늘어감에 따라, 즉 발생되는 트래픽의 양이 줄어듦에 따라 세 개의 $\mathrm{MAC}$ 성능 차이가 크지 않은 것을 알 수 있다. 이것은 트래픽이 감소할수록 전송을 위해 대기하는 패킷의 수 가 줄어들어 트래픽 간 우선순위의 차이가 거의 나지 않기 때 문이다.

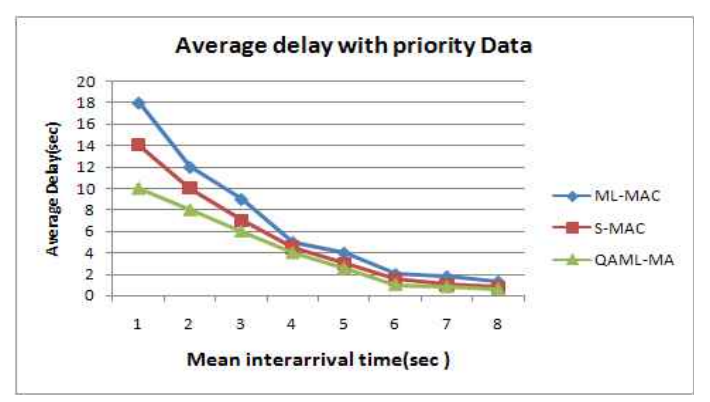

그림 4. 우선순위 데이터의 평균지연

Fig. 4 Average delay with prionity data

아래 그림 5 는 하나의 노드에서 소모하는 평균 에너지에 대한 비교를 보여준다. 그림 5에서 볼 수 있듯이 패킷 도착 간( inter-arrival) 시간에 따른 비교에 있어서 다중 계층을 사용하는 $\mathrm{QAML}-\mathrm{MAC}$ 이나 $\mathrm{ML}-\mathrm{MAC}$ 에서 노드 당 소모하 는 에너지양이 SMAC에 비해 현저히 낮음을 보여 준다. 이는 listen 구간에서 에너지 소모율이 낮을 뿐 만 아니라 전송하 는 패킷의 충돌이 줄어들어 재전송하는데 필요한 에너지가 절 감되었기 때문이다. 또한 $\mathrm{ML}-\mathrm{MAC}$ 과 $\mathrm{QAML}-\mathrm{MAC}$ 의 비교 에서는 큰 차이를 보이지 않지만 이는 전송되어지는 전체 데 이터 중 우선순위의 데이터 비율이 높지 않기 때문이다.

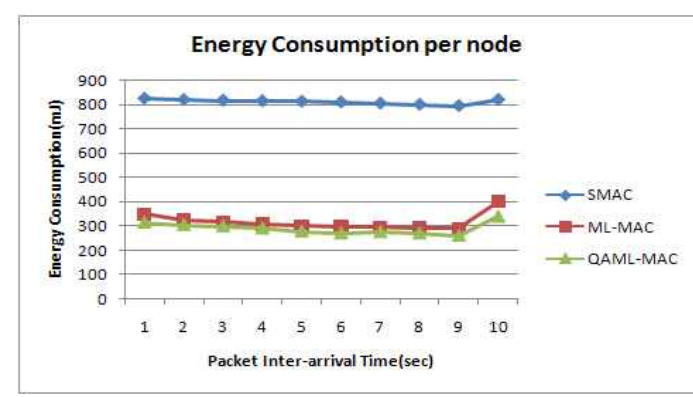

그림 5. 하나의 노드에서의 평균 에너지 소모 Fig. 5. Average Energy Consumption per node

\section{V. 결론}

제한된 에너지의 공급 및 다양한 목적을 가지는 WSNs에 서 지연, 패킷 손실, 대역폭 등의 $\mathrm{QOS}$ 를 지원하기 위해서 기 존의 다른 네트워크에서 제안된 프로토콜을 그대로 적용할 수 없다. 따라서 $\mathrm{WSNs}$ 에서 $\mathrm{QOS}$ 지원에 대한 문제는 많은 연 구자들로 하여금 점점 더 관심의 대상이 되어왔다.

최근에 $\mathrm{MAC}$ 계층에서 $\mathrm{QOS}$ 를 지원하는 프로토콜이 많이 제안되었으나 일반적으로 하나의 계층에 국한되지 않고 물리 계층으로부터 응용계층까지의 요구사항을 만족시키기 위한 cross-layer 프로토콜에 대한 연구가 많이 이루어지고 있는 실정이다.

본 논문에서는 $\mathrm{MAC}$ 계층의 스케줄링 통한 에너지 효율 적이고 지연에 대한 요구사항을 지원할 수 있는 다계층 (multi-layer) $\mathrm{MAC}$ 을 제안하였다. 본 논문에서 제안된 cross-layer $\mathrm{MAC}$ 프로토콜(QAML-MAC)은 에너지의 효 율적인 사용으로 전체네트워크 수명을 늘이면서 각 데이터의 전송 응급성에 따른 $\mathrm{QOS}$ 우선순위를 정하여 차별화된 전송을 할 수 있다. 제안된 $\mathrm{QAML}$ 프로토콜에서 노드들은 우선순위 의 데이터를 전송할 경우의 스케줄과 그렇지 않을 경우 두 개 의 전송 스케줄을 가진다. 뿐 만 아니라 전송 응급성에 따라 결정된 우선순위에 따라 독립의 큐에 저장되며, 저장 시에 동 일한 목적지로 향하는 데이터를 재정돈하여 함께 전송함으로 써 전송 지연을 줄이는 장점을 가진다. 이와 같이 본 논문에 서 제안된 $\mathrm{MAC}$ 프로토콜은 기존에 제안되었던 프로토콜의 문제점인 지연(delay)을 줄이는 동시에 실시간의 멀티미디어 트래픽 혹은 미리 정해진 필드 모니터링과 같은 응용에서 임 계값을 초과하는 데이터와 같은 우선순위가 높은 데이터를 빠 르게 전송함으로써 전송에 응급한 데이터를 먼저 전송할 수 있는 장점을 가진다. 또한 유휴 listening 구간을 여러 계층 으로 구분하여 사용함으로써 전송된 패킷의 충돌을 줄임으로 써 노드에서의 에너지 소모를 줄이는 동시에 전체 네트워크 수명을 늘일 수 있다. 본 논문에서 제안된 QAML-MAC의 정확도를 높이기 위한 각 파라미터들 설정에 대한 연구는 추 후에 이루어질 예정이다.

\section{참고문헌}

[1] W. Ye, J. Heidemann, and D. Estrin, "Medium access control with coordinated adaptive sleeping for 
wireless sensor networks," IEEE/ACM Transaction on Networking, Vol. 12, Issue3, pp. 493-506, June 2004.

[2] T. Dam, K Langendoen, "An Adaptive EnergyEfficient MAC Protocol for Wireless Sensor Networks," ACM Sensys'03, Nov 2003, LA, Califomia, USA

[3] Tang Zhenzhou, Hu Qian, "An Adaptive Low Latency Cross-Layer MAC Protocol for Wireless Sensor Networks," 2009 8th IEEE International Conference on Dependable, Autonomic and Secure Computing, pp. 389-393, 2009.

[4] Liu Yang, Ehanany Itamar, Qi Hairong, "An energy-efficient QQS-aware media access control protocol for wireless sensor networks," Proceedings of the IEEE International Conference on Mbbile Adhoc and Sensor Systems (MASS 2005), Washington, DC, U.S.A, Nov. 2005.

[5] Manish Kumar Jha, Atul Kumar Pandey, Dipankar $\mathrm{Pal}$, Anand Mohan, "An energy-efficient multi-layer MAC(ML-MAC) protocol for wireless sensor networks," International Journal of Electronics and Communications, 2010.

[6] Navrati Saxena, A Roy, and Jitae Shin, "Dynamic duty cycle and adaptive contention window based QOS-MAC protocol for wireless multimedia sensor networks, Computer Networks, vol. 52, pp.2532-2542, 2008.

[7] Hyun Jung Choe, Preetam Ghosh, Sajal K Das, "Q0S-aware data reporting control in cluster-based wireless sensor networks." Computer Communication, vol. 33, pp.1244-1254, 2010.

[8] Yong Yuan, Zongkai Yang, Zhihai He, Jianhua He, "An integrated energy aware wireless transmission system for QOS provisioning in wireless sensor network," Computer Communication, vol. 29, pp.162-172, 2006.

[9] Paek K J, Kim J, Song U S, Hwang C S., "Priority-based medium access control protocol for providing QOS in wireless sensor networks," IEICE Transactions on Information and Systems, 90(9):1448, 2007.

[10] B. Yahya, J. Ben-Othman, "Energy efficient and
QOS aware medium access control for wireless sensor networks," Concurrency and Computation: Practice and Experience, Vol. 22 Issue 10, pp. 1252 - 1266, 2010.

[11] Nikola Zogovica and Goran Dimic, "Wireless Sensor network: QOS Provisioning at MAC and Physical layers," 17th Telecommunication forum TELFOR 2009, Sebia, Belgrade pp.24-26, Nov. 2009.

\section{저 자 소 개}

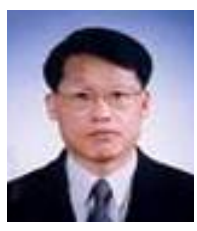

김 성 철

1995년 6월 : Polytechnic University (NY) 공학박사(Ph.D)

1997년 2월 현재 : 상명대학교 교수 <관심분야> WLAN, 센서 네트워크, $\mathrm{Q} 0 \mathrm{~S}$, 멀티미디어 통신

Email: sckim@smu.ac.kr

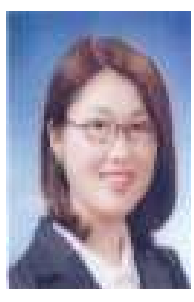

박 현 주

1997년 2월 : 상명대학교 졸업

2000년 2월 : 홍익대학교 전자계산학 석사

2003년3월 현재 :상명대학교 대학원 박사 과정

<관심분야> 무선 센서 네트워크, 클러스터헤드 선정, 무선센서 네트워크에서 Q0S지원

Email: cathy2369@lycos.co.kr 